notably female slavery in Brazil. However, its desired scope as a statement on "Women in the Portuguese Colonial Empire" is over-ambitious. The representation of regions, time periods and specific phases of empire is very uneven, bringing a corresponding looseness of focus to the geographical and historical vectors that structure the book as a whole. Conspicuous by their almost total absence are the former Portuguese colonies in Africa during the Estado Novo, despite the enormous weight this history carries (including, increasingly, work by and about women) in contemporary Portuguese postcolonial discussion of empire. In this context, reducing twentieth-century female experience of colonial Africa to a single piece, however good, on António Lobo Antunes cannot be other than problematic. More specifically, direct engagement with previous work on gender and postcolonial theory, as well as women's history, both in English and Portuguese, would have been helpful here. While it is undoubtedly an important and lasting contribution, Sarmento's book also testifies to the urgency of feminist and postcolonial researchers in Lusophone Studies overcoming historical isolation to create the institutional, textual and virtual settings from which more integrated, systematic approaches can emerge.

Hilary Owen University of Manchester

\title{
Moutinho, Isabel. The Colonial Wars in Contemporary Portuguese Fiction. Woodbridge, UK: Tamesis, 2008.
}

When I read the table of contents of Isabel Moutinho's The Colonial Wars in Contemporary Portuguese Fiction, my first thought was what is this book going to add to the field that other scholars, and particularly Margarida Calafate Ribeiro in her now seminal Uma História de Regressos, have not already covered extensively? The theme of a traumatic memory of the colonial war experience, and the authors and texts studied (particularly Lobo Antunes's Os Cus de Judas, Lídia Jorge's A Costa dos Murmúrios, João de 
Melo's Autópsia de um Mar de Ruínas, and Manuel Alegre's Jornada de África) form the basis of Calafate Ribeiro's book too. Yet, Moutinho's work combines such an original approach to the subject with such rigorous and thoughtful referencing of secondary criticism that I cannot envision teaching or writing about any of these works again without drawing heavily on her contribution. Indeed, the book is structured perfectly so that readers can focus on only the particular close reading in which they are interested on any occasion, while following a logical, narrative flow that entices them to begin at the beginning and read right through to the end. Its usefulness, particularly in the anglophone university setting, is both as the first monograph in English to tackle the subject, and also because of the meticulous way in which Moutinho explains cultural references and intertextual allusions, revealing an immense erudition in Comparative Literature. Most importantly, Moutinho's readings illuminate the texts she scrutinizes. In the very best tradition of literary studies, she makes you want to reread the novels she broaches or to read them for the first time. After reading Moutinho's excellent chapter on Álamo Oliveira's Até Hoje (Memórias de Cão), a novel I am ashamed to admit to not having read previously, I am grateful to her for compelling me to read it by her deft analysis, which centers on writing as a breaking of silence that facilitates a transformation from "passivity to action" (52). A similar breaking of silence, through a registration of "the hushed memory of the colonial war" (77) informs Moutinho's reading of Lídia Jorge. In Melo's work, Moutinho sees the competing force of a national collective memory that, while it never manages to silence completely individual recollections of the colonial disaster, is both powerful and strangely brief, collectively attempting to erase the suffering and sacrifice of Portugal's unwilling soldiers.

Moutinho demonstrates in her reading of Jornada de África the ways in which Manuel Alegre tests our literary memory to the limit through quoting and misquoting an array of other work. What makes Moutinho's reading indis- 
pensable is her referencing and interpretation of those allusions, a strong characteristic of her monograph.

The other work, besides those already mentioned, on which she focuses is Wanda Ramos's Percursos, offering an insightful reading of the text as a narrative of female development and liberation, in which resistance to subalternity is shared by both women and colonial subjects.

Moutinho's introduction contextualizes both the theoretical framework on which she ably draws and its relevance to what she carefully terms the postimperial novels she studies. For Moutinho, it is important to understand the "violence of the colonial fact" (11), a violence often elided in the references of postcolonial studies. Moutinho sees "an allpervasive pessimism" in the novels she considers. They are "gloomy narratives of the end of empire" (12) that counteract the optimistic premises of much of the postcolonial endeavor. Yet, despite their gloom, Moutinho's book shows us why they continue to be important and powerful commentaries on the brutal reality of a deluded regime.

Phillip Rothwell Rutgers University

\section{Simon, Robert. Understanding the Portuguese Poet Joaquim Pessoa, 1942-2007: A Study in Iberian Cultural Hybridity. Lewiston: Edwin Mellen Press, 2008.}

In the United States, the release of a book devoted exclusively to a Portuguese poet is always an infrequent, if welcome, event. The publication of a study on a marginally canonical poet - such as Joaquim Pessoa-constitutes an even more unusual occurrence.

For reasons that have intrigued me for years, some contemporary Portuguese poets are famous, paradoxically, for being "invisible." Such authors are widely recognized for being shunned (often unfairly) by both academic and nonacademic communities of critics, although not necessarily by the general public: for example, Fernando Grade (a productive and notoriously eccentric author), as well as Pedro 